Sains Malaysiana 47(4)(2018): 661-670

http://dx.doi.org/10.17576/jsm-2018-4704-03

\title{
5-Aminolevulinic Acid Induces Regulation in Growth, Yield and Physio- Biochemical Characteristics of Wheat under Water Stress
}

(Asid 5-aminolevulinik Mengaruh Pengawalaturan terhadap Pertumbuhan, Hasilan dan Ciri Fisio-Biokimia Gandum pada Tekanan Air)

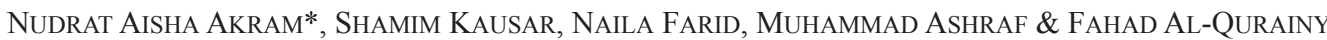

\section{ABSTRACT}

The production of wheat crop is below average in many regions of the world which is ascribed to adverse environmental conditions including drought stress. The present study was conducted to appraise the beneficial role of exogenouslyapplied 5-aminolevulinic acid (ALA) on growth, yield and some key physio-biochemical characteristics of two commercially important wheat cultivars (Shafaq-06 and Uqab-2000) under well watered [100\% field capacity (FC)] and water-deficit (60 and $80 \% \mathrm{FC}$ ) conditions. Imposition of varying water regimes significantly decreased fresh and dry weights of shoots, photosynthetic pigments ( $a$ and b), non-photochemical quenching of chlorophyll fluorescence (NPQ), quenching coefficient for non-photochemical ( $N$ ) of chlorophyll fluorescence $(q N), K^{+}$(potassium ion), $\mathrm{Ca}^{2+}$ (calcium ion) and $P$ (phosphorus) accumulation in shoot and root and yield-related attributes. In contrast, water deficit regimes caused improvement in $F_{v} / F_{m}$ (chlorophyll fluorescence measurement), coefficient of photochemical quenching (qP), proline, glycinebetaine (GB) and hydrogen peroxide $\left(\mathrm{H}_{2} \mathrm{O}_{2}\right)$ contents. Foliar spray of ALA at the rate of 50, 100 and $150 \mathrm{mg} / \mathrm{L}$ along with control (no spray (NS) and/or water spray (WS)) significantly enhanced chlorophyll a and b pigments, $q N, N P Q, q P, K^{+}, C a^{2+}$ and $P$ accumulation in both roots and shoots, proline, GB, total phenolics and malondialdehyde (MDA) contents and yield. The wheat Shafaq-06 was better in shoot dry weight, $q N, N P Q$ and $F_{v} / F_{m}$, shoot and root $K^{+}$, root $\mathrm{Ca}^{2+}$, proline, GB accumulation and yield attributes, while Uqab-2000 was better in chlorophyll a contents, root $P$ and MDA contents. Overall, better growth and yield of Shafaq-06 than Uqab-2000 under water deficit regimes was found to be associated with ALA improved leaffluorescence $\left(q N, N P Q\right.$ and $\left.F_{v} / F_{m}\right)$, shoot and root $\mathrm{K}^{+}$, root $\mathrm{Ca}^{2+}$, proline and GB accumulation.

Keywords: Chlorophyll contents; drought stress; wheat; yield; 5-Aminolevulinic acid

\section{ABSTRAK}

Penghasilan tanaman gandum adalah di bawah purata di kebanyakan kawasan di dunia dianggap sebagai keadaan alam sekitar yang buruk termasuk tekanan kemarau. Kajian ini dijalankan untuk menilai kelebihan eksogen-aplikasi 5-aminolevulinik asid (ALA) terhadap pertumbuhan, hasilan dan ciri-ciri fisio-biokimia kedua-dua kultivar gandum yang komersial utama (Shafaq-06 dan Uqab-2000) dalam keadaan kecukupan air [100\% keupayaan lading (FC)] dan defisit air (60 dan 80\% FC). Pengenaan rejim air yang berbeza telah mengurangkan berat segar dan kering tunas secara berkesan, pigmen fotosintetik (a dan b), pelindapan tanpa fotokimia fluoresens klorofil (NPQ), pekali pelindapan untuk tanpa fotokimia $(N)$ fluoresens klorofil $(q N), K^{+}$(ion kalium), $\mathrm{Ca}^{2+}$ (ion kalsium) dan P (fosforus) pengumpulan pada tunas, akar serta sifat berkaitan hasilan. Sebaliknya, rejim defisit air menyebabkan penambahbaikan $F_{v} / F_{m}$ (pengukuran fluoresens klorofil), pekali pelindapan fotokimia (qP), kandungan prolina, glycinebetaine (GB) dan hidrogen peroksida $\left(\mathrm{H}_{2} \mathrm{O}_{2}\right.$ ). Semburan daun ALA pada kadar 50, 100 dan $150 \mathrm{mg} / \mathrm{L}$ selari dengan kawalan (tanpa semburan (NS) dan semburan air (WS)) meningkat dengan ketara pengumpulan pigmen klorofil a dan $b, q N, N P Q, q P, K^{+}, C a^{2+}$ dan $P$ pada akar dan tunas, serta kandungan dan hasilan prolina, GB, jumlah fenolik dan malondialdehid (MDA). Gandum Shafaq-06 lebih baik dalam berat kering tunas, $q N, N P Q$ dan $F_{V} / F_{m}$, tunas dan akar $K^{+}$, tunas dan akar $\mathrm{Ca}^{2+}$, prolina, pengumpulan GB dan sifat hasilan, manakala Uqab-2000 lebih baik dalam kandungan klorofil a, tunas P dan kandungan MDA. Keseluruhannya, pertumbuhan dan hasilan Shafaq-06 lebih baik daripada Uqab-2000 dalam regim defisit air adalah berkaitan dengan ALA yang dapat pernambahbaik flurosens daun $\left(q N, N P Q\right.$, dan $\left.F_{v} / F_{m}\right)$, tunas dan akar $K^{+}$, akar $C a^{2+}$, prolina dan pengumpulan $G B$.

Kata kunci: Asid 5-aminolevulinik; gandum; hasilan; kandungan klorofil; tekanan kemarau

\section{INTRODUCTION}

Water shortage is a devastating environmental stress which adversely affects growth, production and development of crop plants (Ashraf et al. 2011). At all stages of plant growth, drought stress acts as a limiting factor. Water stress is believed to alter many biochemical and physiological 
processes such as nutrient uptake and metabolism, water relations, osmotic adjustment, photosynthesis, respiration, fluorescence and energy metabolism (Ashraf et al. 2011). Plants have developed a wide range of mechanisms to maintain survival and productivity under water deficit conditions (Akram et al. 2007; Ashraf et al. 2011). Many defensive mechanisms help the plant to stay alive and develop properly before the reproductive stage i.e. up-regulation of antioxidants, osmo-regulation, ionic homeostasis and hormonal system (Akram \& Ashraf 2013). Drought stress promotes the rate of synthesis of reactive oxygen species (ROS) (Navarri-Izzo et al. 1994), however, plants produce different antioxidants and osmolytes to neutralize ROS under drought stress (Ashraf 2009; Mittler 2002). According to a prediction, 1.8 billion people i.e. $65 \%$ of the total world's population will face water deficient conditions up to 2025 (Nezhadahmadi et al. 2013).

Aminolevulinic acid (ALA), a five carbon plant growth regulator (Akram \& Ashraf 2013; Naeem et al. 2010) is involved in the biosynthesis of phycobilins, chlorophyll, vitamin $B_{12}$ and heme in plants (Akram \& Ashraf 2013). Generally, optimal production of ALA is necessary in order to synthesize optimal levels of chlorophyll in plants. If the natural production of this biomolecule is very low in a plant, then this deficiency can be overcome by its exogenous application. It is strongly believed that exogenous application of ALA can effectively stimulate a number of physiological processes including biosynthesis of chlorophyll and photosynthates under stress and nonstress conditions (Akram \& Ashraf 2013, 2011b). For example, ALA improved photosynthesis in strawberry (Liu et al. 2006), pakchoi (Wang et al. 2004), spinach (Nishihara et al. 2003) and radish (Wang et al. 2005). In view of some reports ALA can enhance agricultural productivity under drought stress due to increase in photosynthetic rate (Wang et al. 2003), antioxidants, nitrogen and carbon fixing processes (Maruyama-Nakashita et al. 2010). It is now widely known that ALA containing fertilizers improves photosynthetic assimilation (Youssef \& Awad 2008) and provides protection against insects and herbs (Duke \& Rebeiz 1994).

Production of wheat is below from average in many regions of the world mainly due to unfavorable climatic factors. Drought is one of the main environmental cues affecting quantity and quality of wheat all-over the world. Generally, different physio-biochemical processes, growth and yield of wheat plants are affected due to insufficient irrigation (Metwaly 2012). Therefore, an experiment was carried-out to examine whether exogenous application of ALA could enhance plant growth and/or yield by altering different physiological attributes of wheat under water deficit regimes.

\section{MATERIALS AND Methods}

A completely randomized design (CRD) experiment with four replicates in a three factor factorial arrangement was conducted from November 2012 to April 2013. Two wheat cultivars, Shafaq-06 and Uqab-2000, were grown under different (control, 80\% and 60\% field capacity; FC) water deficit regimes. Plastic pots filled with $6000 \mathrm{~g}$ sandy-loam soil were used. During growing season, RH (relative humidity) was 33.0-63.0\%, day/night temperature was $31 \pm 3.5^{\circ} \mathrm{C} / 26.5 \pm 2{ }^{\circ} \mathrm{C}$ and day-length was 11 to $12 \mathrm{~h}$. Six seeds were planted in each plastic pot and normal watering was done before seed germination. After germination, thinning of plants was done and four seedlings were maintained per pot. After 20 days of seed germination, water stress treatments were maintained up to the yield on the basis of FC. After 30 days of initiation of drought stress treatments when the wheat plants were at the vegetative stage, different levels (NS, WS, 50, 100 and $150 \mathrm{mg} / \mathrm{L}$ ) of ALA were applied foliarly. After 14 days of ALA spray, leaf samples for key variables were collected and stored at freezing temperature $\left(-20^{\circ} \mathrm{C}\right)$. Then, two plants per treatment were harvested and rinsed with tap water. After separating roots and shoots, fresh weights were recorded and then placed in an oven for 3 days at $70^{\circ} \mathrm{C}$. The dry weights were measured. The remaining two plants in each pot were allowed to grow up till yield formation. The following attributes were determined during the study:

\section{CHLOROPHYLL FLUORESCENCE}

Using a chlorophyll fluorometer (Model, Multi-ModeOS5P, USA), chlorophyll fluorescence attributes were recorded of intact leaves following Strasser et al. (1995).

\section{CHLOROPHYLL CONTENTS}

Photosynthetic pigments were analyzed pursuing the method of Arnon (1949). $500 \mathrm{mg}$ Fresh leaf was collected in an ice containing container. Then, it was extracted in $10 \mathrm{~mL}(\mathrm{v} / \mathrm{v})$ acetone (80\%). The O.D (optical density) of the filtrate was read using a UV-visible spectrophotometer (IRMECO, U2020, Germany) at 645 and $663 \mathrm{~nm}$.

\section{MINERAL NUTRIENTS $\left(\mathrm{K}^{+}, \mathrm{CA}^{2+}\right.$ AND P)}

The method of Wolf (1982) was used to digest plant material for analyzing different inorganic nutrients. The values of $\mathrm{K}^{+}$and $\mathrm{Ca}^{2+}$ in the aliquots were recorded using a flame photometer (Jenway, PFP-7). Phosphorus was determined according to the method of Jackson (1962).

\section{FREE PROLINE}

Fresh leaf material (500 mg) was extracted with 3\% sulfosalicylic acid following the method of Bates et al. (1973).

\section{GLYCINEBETAINE (GB)}

A total of $250 \mathrm{mg}$ dry leaf was mixed with $5 \mathrm{~mL} 0.5 \%$ toluene and kept overnight at $4^{\circ} \mathrm{C} .1 .0 \mathrm{~mL} 2 \mathrm{~N} \mathrm{H}_{2} \mathrm{SO}_{4}$ (sulfuric acid) was added to $1 \mathrm{~mL}$ filtrate and mixed. Then, $0.2 \mathrm{~mL} \mathrm{KI}_{3}$ (potassium tri-iodide) solution was added to $0.5 \mathrm{~mL}$ mixture. This mixture was mixed well and cooled in an ice bath. The absorbance of the lower organic layer 
was recorded at $365 \mathrm{~nm}$ using a spectrophotometer (Grieve \& Grattan 1983).

\section{HYDROGEN PEROXIDE $\left(\mathrm{H}_{2} \mathrm{O}_{2}\right)$}

In a pre-chilled mortar, $500 \mathrm{mg}$ fresh leaf material was ground in $5 \mathrm{~mL} 0.1 \%$ TCA (trichloroacetic acid solution) and centrifuged for $15 \mathrm{~min}$ at $12,000 \times \mathrm{g}$ following Velikova et al. (2000).

\section{MALONDIALDEHYDE (MDA)}

A total of $250 \mathrm{mg}$ fresh leaf was extracted in $3 \mathrm{~mL} 1 \%$ TCA under chilling conditions. $1 \mathrm{~mL}$ of the supernatant was mixed with $4 \mathrm{~mL} 0.5 \%$ TBA (thiobarbituric acid) and the mixture was incubated at $95^{\circ} \mathrm{C}$ for $1 \mathrm{~h}$. After cooling, the absorbance of the supernatant was read at 532 and 600 nm (Carmak \& Horst 1991).

\section{TOTAL PHENOLICS}

Leaf total phenolics were examined following JulkenenTitto (1985).

\section{STATISTICAL ANALYSIS}

A three-factor (cultivars, drought stress and ALA) factorial randomized design with four replicates was employed. Mean square values were obtained through analysis of variance (ANOVA) technique using Costat version 3.0 (MSTAT Development Team 1989).

\section{RESULTS AND DISCUSSION}

Under water-deficit conditions ( $60 \%$ and $80 \%$ FC), shoot fresh and dry weights of both wheat cultivars decreased $(p \leq 0.001)$ considerably as compared to the plants grown under well watered conditions. Different levels (50, 100 and $150 \mathrm{mg} / \mathrm{L}$ ) of ALA slightly improved shoot fresh and dry weights in both wheat genotypes under all water regimes. Both wheat cultivars were similar in shoot fresh weight, while wheat Shafaq-06 was slightly superior to the other wheat cultivar in shoot dry weight under water stress (Table $1 \&$ Figure 1). Water is a crucial entity for all organisms including plants because functioning of all metabolic processes depends on it (Ashraf et al. 2011). Plant growth and yield reduction due to water deficiency appearing at any plant growth stage has been well studied (Pervez et al. 2009). However, this study was carried out to observe the effectiveness of ALA on growth, yield and some key physio-biochemical characteristics of wheat plants under well watered (100\% FC) and water-deficit (60\% and $80 \%$ FC) conditions. Foliar-applied with 100 and $150 \mathrm{mg} / \mathrm{L} 5$-aminolevulinic acid (ALA) reduced the drought-induced inhibition in plant growth (shoot fresh and dry weights) of both wheat cultivars. This is comparable to what has already been observed in cucumber plants when Li et al. (2011) applied $3 \mu \mathrm{M}$ ALA as a seed pretreatment. They found a significant improvement in plant growth under drought stress. In addition, they attributed this improvement to ALA-induced increase in antioxidant enzyme activities and reduction in ROS generation. In another study, Liu et al. (2013) observed that foliar-applied $\mathrm{ALA}$ at the rate of $30 \mathrm{mg} / \mathrm{L}$ considerably maintained water stress-affected chlorophyll contents, water status in terms of RWC (relative water content), photosynthetic capacity, $F_{v} / F_{m}, q P, N P Q$ and electron transport rates of rapeseed plants. Furthermore, foliar-applied ALA also suppressed the drought-induced accumulation of $\mathrm{H}_{2} \mathrm{O}_{2}$ and MDA coupled with improved activities of different (CAT (catalase) \& POD (peroxidase)) antioxidant enzymes (Liu et al. 2013). Similarly, in our study, foliar-applied ALA also decreased drought-induced increase in $\mathrm{H}_{2} \mathrm{O}_{2}$ contents.

Chlorophyll contents ( $a$ and $b$ ) reduced considerably ( $P \leq 0.001$ and $P \leq 0.05$, respectively) under different water regimes (Figure 1). Higher reduction in chlorophyll pigments was observed at $60 \% \mathrm{FC}$ as compared to that of control (100\% FC) and mild (80\% FC) water stress conditions. ALA improved photosynthetic pigments and maximum improvement in chlorophyll $a$ and $b$ contents was found at 100 and $150 \mathrm{mg} / \mathrm{L}$ levels of ALA particularly under water stress conditions. Cultivar Uqab had higher chlorophyll $a$ contents than the other cultivar under stress conditions in particular at $60 \%$ FC. While both wheat cultivars showed a similar trend in chlorophyll $b$ contents under different water regimes and exogenously applied ALA.

5-Aminolevulinic acid-induced modifications in multiple physiological processes of different crops have been observed under different environmental conditions including drought stress (Akram \& Ashraf 2013, 2011a, 2011b; Liu et al. 2013). In this study, ALA improved chlorophyll of wheat plants under all water regimes. ALA-induced improvement in chlorophyll contents under water-deficit conditions has already been observed in maize (Dolatabadian et al. 2009), oilseed rape (Liu et al. 2013, 2011) and Phoenix dactylefera (Youssef \& Awad 2008). ALA is known as one of the major precursors of chlorophyll biosynthesis, so increase in chlorophyll content under stress and non-stress conditions could be attributed to increased endogenous level of ALA following its external application. Of different leaf fluorescence attributes, $q N$ and NPQ of all the plants decreased under water stress. However, photochemical quenching $(q P)$ and efficiency of PS-II (measured as $F_{v} / F_{m}$ ) increased significantly under water-deficit conditions as compared to those in $100 \%$ FC. Exogenously-applied varying levels of ALA considerably improved all the above-mentioned leaf fluorescence attributes except $F_{v} / F_{m}$. Overall, cultivar Shafaq-06 was better in $q N, N P Q$ and $F_{v} / F_{m}$ as compared to cultivar Uqab2000 under both water regimes (Figure 1).

Accumulation of $\mathrm{K}^{+}, \mathrm{Ca}^{2+}$ and $\mathrm{P}$ in shoot and root decreased significantly in both wheat cultivars due to imposition of different water regimes (Table 1; Figure 2). Varying levels of foliar-applied ALA improved accumulation of $\mathrm{K}^{+}, \mathrm{Ca}^{2+}$ and $\mathrm{P}$ in both roots and shoots of both wheat cultivars under 60,80 and $100 \%$ FC (Figure 2 ). Occurrence of nutritional imbalance in plant cells/ tissues is one of the major physiological disorders caused 
TABLE 1. Mean square (ANOVA) data for growth, yield and some key physio-biochemical attributes of wheat plants subjected to foliar-applied varying levels of 5-aminolevulinic acid (ALA) under water-stressed and non-stressed conditions

\begin{tabular}{|c|c|c|c|c|c|c|}
\hline Source of variation & df & Shoot FW & Shoot DW & Chl. $a$ & Chl. $b$ & $q N$ \\
\hline Cultivars (Cvs) & 1 & $1.397 * *$ & $0.0003 \mathrm{~ns}$ & $3.111 * * *$ & $1.133 \mathrm{~ns}$ & $0.384 * * *$ \\
\hline Drought stress (D) & 2 & $2.100 * * *$ & $0.487 * * *$ & $2.048 * * *$ & $1.267^{*}$ & $0.293 * * *$ \\
\hline ALA & 4 & $0.224 \mathrm{~ns}$ & $0.027 \mathrm{~ns}$ & $0.669 * * *$ & $0.929 *$ & $0.093 * * *$ \\
\hline $\mathrm{Cvs} \times \mathrm{D}$ & 2 & $0.021 \mathrm{~ns}$ & $0.059^{*}$ & $0.372 *$ & $0.270 \mathrm{~ns}$ & $0.034 * * *$ \\
\hline $\mathrm{Cvs} \times \mathrm{ALA}$ & 4 & $0.036 \mathrm{~ns}$ & $0.005 \mathrm{~ns}$ & $0.124 \mathrm{~ns}$ & $0.073 \mathrm{~ns}$ & $0.012 *$ \\
\hline $\mathrm{D} \times \mathrm{ALA}$ & 8 & $0.014 \mathrm{~ns}$ & $0.008 \mathrm{~ns}$ & $0.165 \mathrm{~ns}$ & $0.231 \mathrm{~ns}$ & $0.016 * * *$ \\
\hline \multirow[t]{2}{*}{$\mathrm{Cvs} \times \mathrm{D} \times \mathrm{ALA}$} & 8 & $0.044 \mathrm{~ns}$ & $0.013 \mathrm{~ns}$ & $0.120 \mathrm{~ns}$ & $0.307 \mathrm{~ns}$ & $0.009 *$ \\
\hline & $\mathrm{df}$ & $\mathrm{F}_{\mathrm{v}} / \mathrm{F}_{\mathrm{m}}$ & NPQ & $q P$ & Shoot $\mathrm{K}^{+}$ & Root $\mathrm{K}^{+}$ \\
\hline Cultivars (Cvs) & 1 & $0.207 * * *$ & $2.624 * * *$ & $0.0855 \mathrm{~ns}$ & $1162.5^{* * *}$ & $1928.0 * * *$ \\
\hline Drought stress (D) & 2 & $0.025 * * *$ & $1.057 * * *$ & $0.433 * * *$ & $259.6^{*}$ & $265.0 * * *$ \\
\hline ALA & 4 & $0.019 * * *$ & $0.480 * * *$ & $0.296 * * *$ & $495.1 * * *$ & $233.9 * * *$ \\
\hline $\mathrm{Cvs} \times \mathrm{D}$ & 2 & $0.021 * * *$ & $0.123 * *$ & $0.077^{*}$ & $154.5 \mathrm{~ns}$ & $43.72 \mathrm{~ns}$ \\
\hline $\mathrm{Cvs} \times \mathrm{ALA}$ & 4 & $0.004 \mathrm{~ns}$ & $0.071 *$ & $0.037 \mathrm{~ns}$ & $19.98 \mathrm{~ns}$ & $56.81 \mathrm{~ns}$ \\
\hline $\mathrm{D} \times \mathrm{ALA}$ & 8 & $0.020 * * *$ & $0.05 *$ & $0.014 \mathrm{~ns}$ & $141.3 \mathrm{~ns}$ & $32.15 \mathrm{~ns}$ \\
\hline \multirow[t]{2}{*}{$\mathrm{Cvs} \times \mathrm{D} \times \mathrm{ALA}$} & 8 & $0.008 * * *$ & $0.084 * * *$ & $0.025 \mathrm{~ns}$ & $188.9^{*}$ & $11.41 \mathrm{~ns}$ \\
\hline & $\mathrm{df}$ & Shoot $\mathrm{Ca}^{2+}$ & Root $\mathrm{Ca}^{2+}$ & Shoot P & Root P & Proline \\
\hline Cultivars (Cvs) & 1 & $7.252 \mathrm{~ns}$ & $902.5 * * *$ & $0.0035 \mathrm{~ns}$ & $0.0003 * * *$ & $59.17 * * *$ \\
\hline Drought stress (D) & 2 & $242.5^{* * *}$ & $116.4 * * *$ & $0.0007 * *$ & $0.00047 * * *$ & $9.155^{*}$ \\
\hline ALA & 4 & $79.89 * * *$ & $67.3 * * *$ & $0.0008 * * *$ & $0.00002 * * *$ & $18.015 * * *$ \\
\hline $\mathrm{Cvs} \times \mathrm{D}$ & 2 & $22.15 \mathrm{~ns}$ & $34.53 *$ & $0.0001 \mathrm{~ns}$ & $0.00003 * * *$ & $0.0089 \mathrm{~ns}$ \\
\hline $\mathrm{Cvs} \times \mathrm{ALA}$ & 4 & $2.793 \mathrm{~ns}$ & $71.88 * * *$ & $0.00007 \mathrm{~ns}$ & $0.000019 * * *$ & $2.486 \mathrm{~ns}$ \\
\hline $\mathrm{D} \times 5$-ALA & 8 & $6.211 \mathrm{~ns}$ & $14.05 \mathrm{~ns}$ & $0.00007 \mathrm{~ns}$ & $0.0002 \mathrm{~ns}$ & $1.375 \mathrm{~ns}$ \\
\hline \multirow[t]{2}{*}{$\mathrm{Cvs} \times \mathrm{D} \times \mathrm{ALA}$} & 8 & $42.73 * *$ & $9.082 \mathrm{~ns}$ & $0.00001 \mathrm{~ns}$ & $0.0004 \mathrm{~ns}$ & $2.525 \mathrm{~ns}$ \\
\hline & $\mathrm{df}$ & GB & Total Phenolics & MDA & $\mathrm{H}_{2} \mathrm{O}_{2}$ & 100-grain weight \\
\hline Cultivars (Cvs) & 1 & $9278.2 * * *$ & $7.413 \mathrm{~ns}$ & $8600446.0 * * *$ & $131920.4 \mathrm{~ns}$ & $6.31 * * *$ \\
\hline Drought stress (D) & 2 & $15484.3 * * *$ & $55.98 \mathrm{~ns}$ & $1539561.4 \mathrm{~ns}$ & $890373.2 * * *$ & $5.32 * * *$ \\
\hline ALA & 4 & $1959.5 * *$ & $326.8 * * *$ & $2865627.1 * * *$ & $116812.6^{*}$ & $4.35 * * *$ \\
\hline $\mathrm{Cvs} \times \mathrm{D}$ & 2 & $9763.4 * * *$ & $124.9 \mathrm{~ns}$ & $2928279.5 * *$ & $343163.9 * * *$ & $0.100 \mathrm{~ns}$ \\
\hline $\mathrm{Cvs} \times$ ALA & 4 & $244.2 \mathrm{~ns}$ & $51.49 \mathrm{~ns}$ & $1358985.5^{*}$ & $29430.5 \mathrm{~ns}$ & $0.159 \mathrm{~ns}$ \\
\hline $\mathrm{D} \times \mathrm{ALA}$ & 8 & $305.7 \mathrm{~ns}$ & $96.97 *$ & $414547.5 \mathrm{~ns}$ & $31664.5 \mathrm{~ns}$ & $0.128 \mathrm{~ns}$ \\
\hline \multirow[t]{2}{*}{$\mathrm{Cvs} \times \mathrm{D} \times \mathrm{ALA}$} & 8 & $327.8 \mathrm{~ns}$ & $108.5^{*}$ & $365203.1 \mathrm{~ns}$ & $25213.7 \mathrm{~ns}$ & $0.271 \mathrm{~ns}$ \\
\hline & $\mathrm{df}$ & $\begin{array}{c}\text { No of grains/ } \\
\text { plant }\end{array}$ & $\begin{array}{c}\text { Grain yield/ } \\
\text { plant }\end{array}$ & & & \\
\hline Cultivars (Cvs) & 1 & $9.847 \mathrm{~ns}$ & $1.281 \mathrm{~ns}$ & & & \\
\hline Drought stress (D) & 2 & $291.5 * * *$ & $26.44 * * *$ & & & \\
\hline ALA & 4 & $36.61 *$ & $2.347^{*}$ & & & \\
\hline $\mathrm{Cvs} \times \mathrm{D}$ & 2 & $8.88 \mathrm{~ns}$ & $1.007 \mathrm{~ns}$ & & & \\
\hline $\mathrm{Cvs} \times \mathrm{ALA}$ & 4 & $7.57 \mathrm{~ns}$ & $0.877 \mathrm{~ns}$ & & & \\
\hline $\mathrm{D} \times \mathrm{ALA}$ & 8 & $5.851 \mathrm{~ns}$ & $0.326 \mathrm{~ns}$ & & & \\
\hline $\mathrm{Cvs} \times \mathrm{D} \times \mathrm{ALA}$ & 8 & $5.315 \mathrm{~ns}$ & $0.620 \mathrm{~ns}$ & & & \\
\hline
\end{tabular}

ns $=$ non-significant; $*$, ** and $* * *=$ significant at $0.05,0.01$ and 0.001 levels, respectively; FW, Fresh weight; DW, Dry weight; MDA, Malondialdehyde; $\mathrm{H}_{2} \mathrm{O}_{2}$, Hydrogen oxide; GB, Glycinebetaine

by water shortage (Ashraf et al. 2011). We observed that $\mathrm{K}^{+}, \mathrm{Ca}^{2+}$ and $\mathrm{P}$ accumulation in shoot and root was suppressed under water deficit conditions similar to that in wheat under saline stress (Ashraf \& Khanum 1997) and exogenously applied ALA levels were effective in improving accumulation of these ions in both wheat 


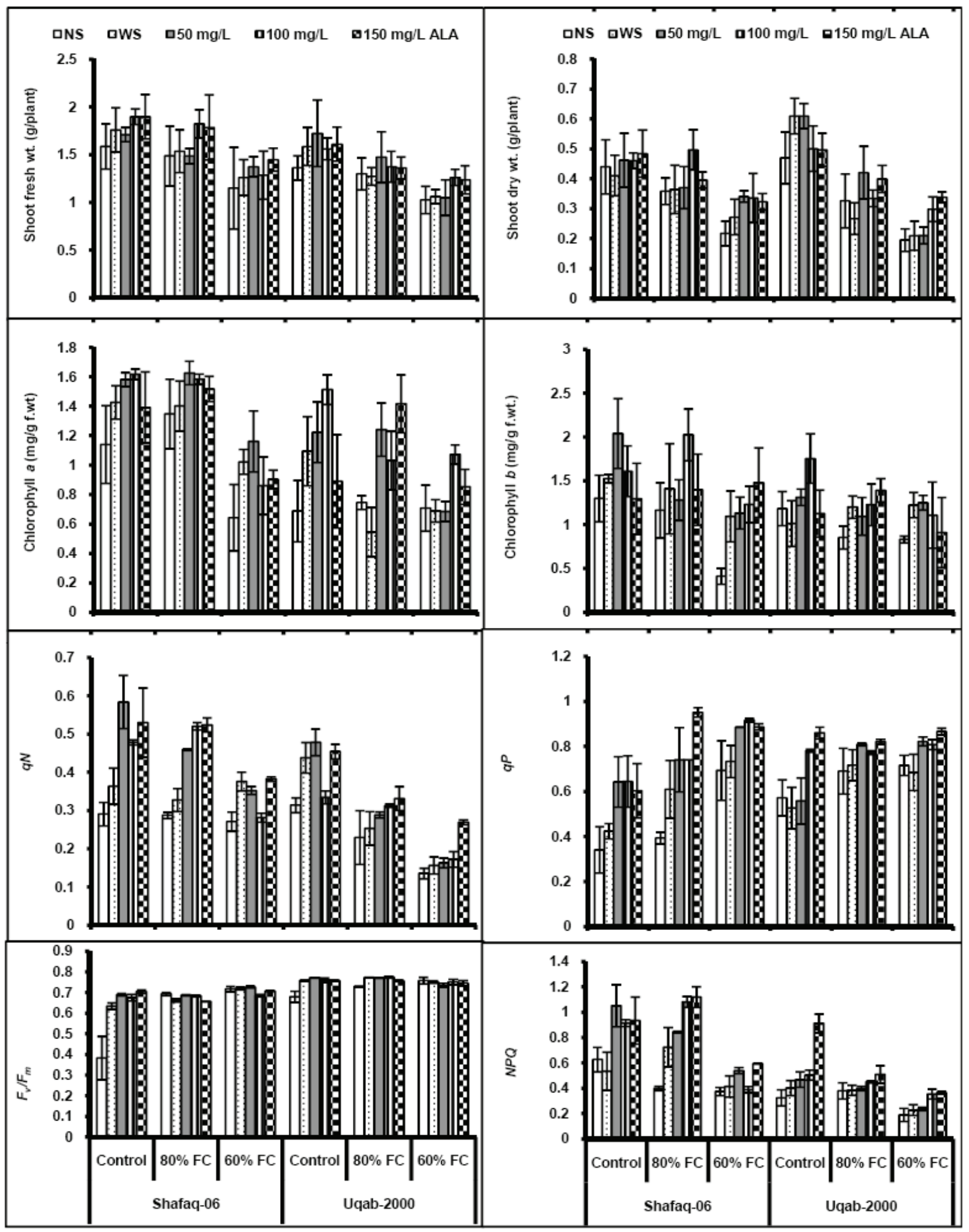

FIGURE 1. Shoot fresh and dry weights, chlorophyll $a$ and $b$ contents and different leaf fluorescence attributes of wheat plants treated with aminolevulinic acid (ALA) foliarly at vegetative stage under control and drought stress $(60 \% \& 80 \%$ field capacity) conditions $($ Mean \pm S.E)

cultivars at all water regimes. Earlier to the present study, not a single report is available in the literature on ALA induced changes in mineral nutrient accumulation in plants subjected to drought stress conditions. However, under saline conditions, Akram and Ashraf (2011a) observed that exogenously-applied ALA altered the uptake of $\mathrm{Na}^{+}$ and $\mathrm{K}^{+}$in the roots of sunflower plants. In addition, $\mathrm{Na}^{+}$ accumulation declined significantly in salt-stressed plants of cotton (Watanabe et al. 2000), P. dactylifera (Youssef \& Awad 2008) and oilseed rape (Naeem et al. 2010) by exogenously applied ALA. Therefore, further research needs to find out ALA-induced effectiveness in pattern of uptake and accumulation of different nutrients in plants of different species under drought stress. 
High free proline contents were observed in both wheat cultivars due to water stress particularly at $80 \%$ FC (Figure 2). ALA improved proline accumulation in all wheat plants subjected to all water stress levels. Cultivar Shafaq-06 being better than cultivar Uqab-2000 in this variable. Drought stress-induced increase $(P \leq 0.001)$ in GB contents was observed only in wheat Shafaq-06, while GB accumulation in wheat Uqab-2000 remained almost unchanged under well-watered and water-deficit conditions (Table 1; Figure 2). ALA-induced considerable improvement in GB accumulation was observed. Of all the ALA levels, 100 and $150 \mathrm{mg} / \mathrm{L}$ were found to be the most effective. Osmoregulation/osmotic adjustment caused by accumulation of osmotica in high concentration is one of the promising strategies of plants for maintaining plant growth as well as yield under low water environment
(Ashraf et al. 2011). High accumulation of proline and GB in response to drought stress has been observed in many plants such as rice (Cha-um et al. 2013), okra (Sankar et al. 2007) and sunflower (Iqbal et al. 2005), which induced drought tolerance in these plant species. All these reports are analogous to what has been observed in the present study as increased accumulation of GB and proline also occurred in wheat plants grown under drought conditions. In the present study, exogenously-applied ALA enhanced GB and proline accumulation in drought-stressed wheat plants, but not a single report is available on the effect of ALA on proline or GB stimulation in growth under water deficit with which our findings could be compared. However, there are some other studies on the effect of ALA on the accumulation of these osmoprotectants under stress conditions other than drought. For example, ALA caused

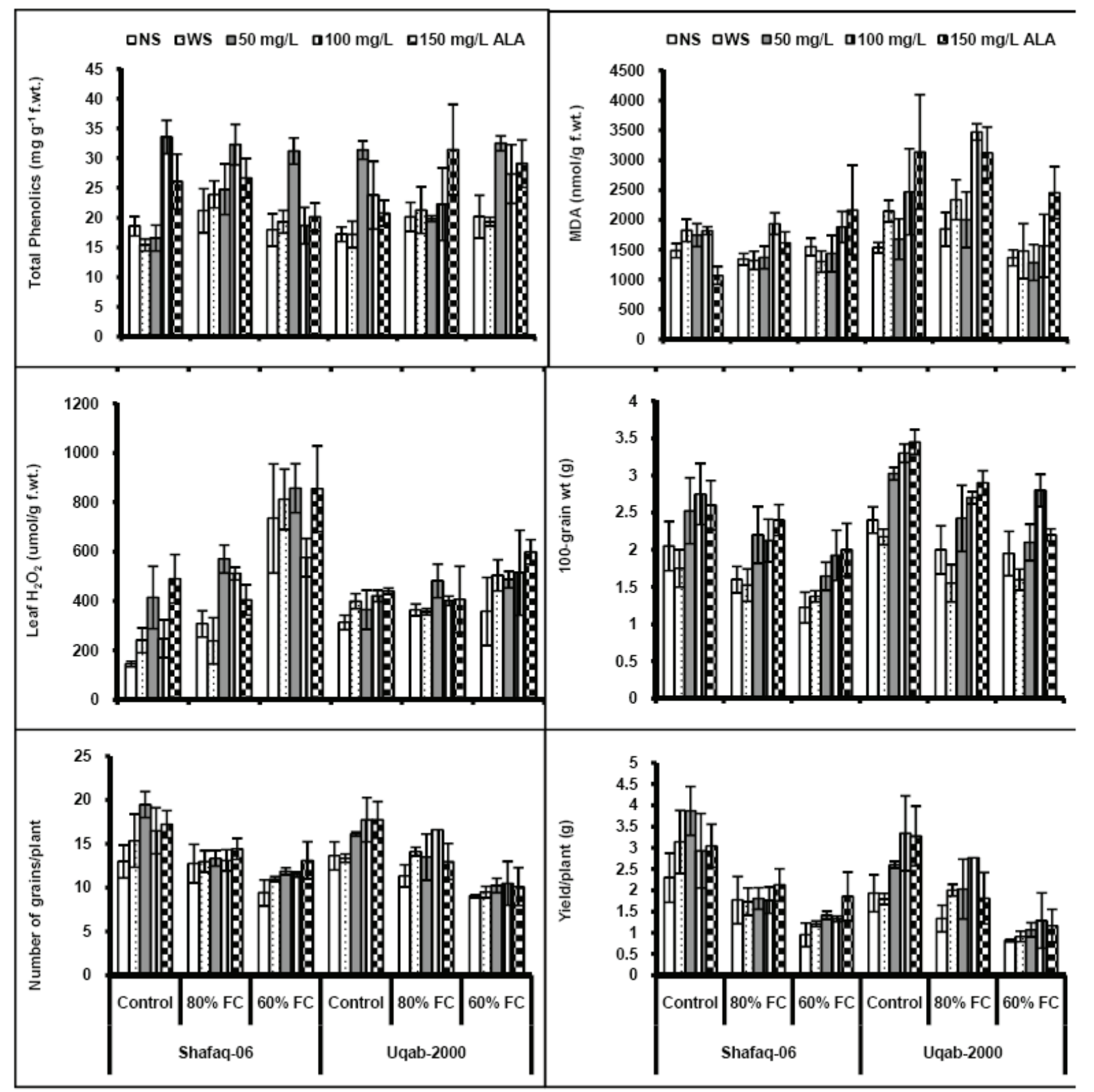

FIGURE 2. Shoot and root $\mathrm{K}^{+}, \mathrm{Ca}^{2+}$ and $\mathrm{P}$ and leaf glycinebetaine (GB) and free proline contents of wheat plants treated with aminolevulinic acid (ALA) foliarly at vegetative stage under control and drought stress $(60 \%$ \& $80 \%$ field capacity) conditions 


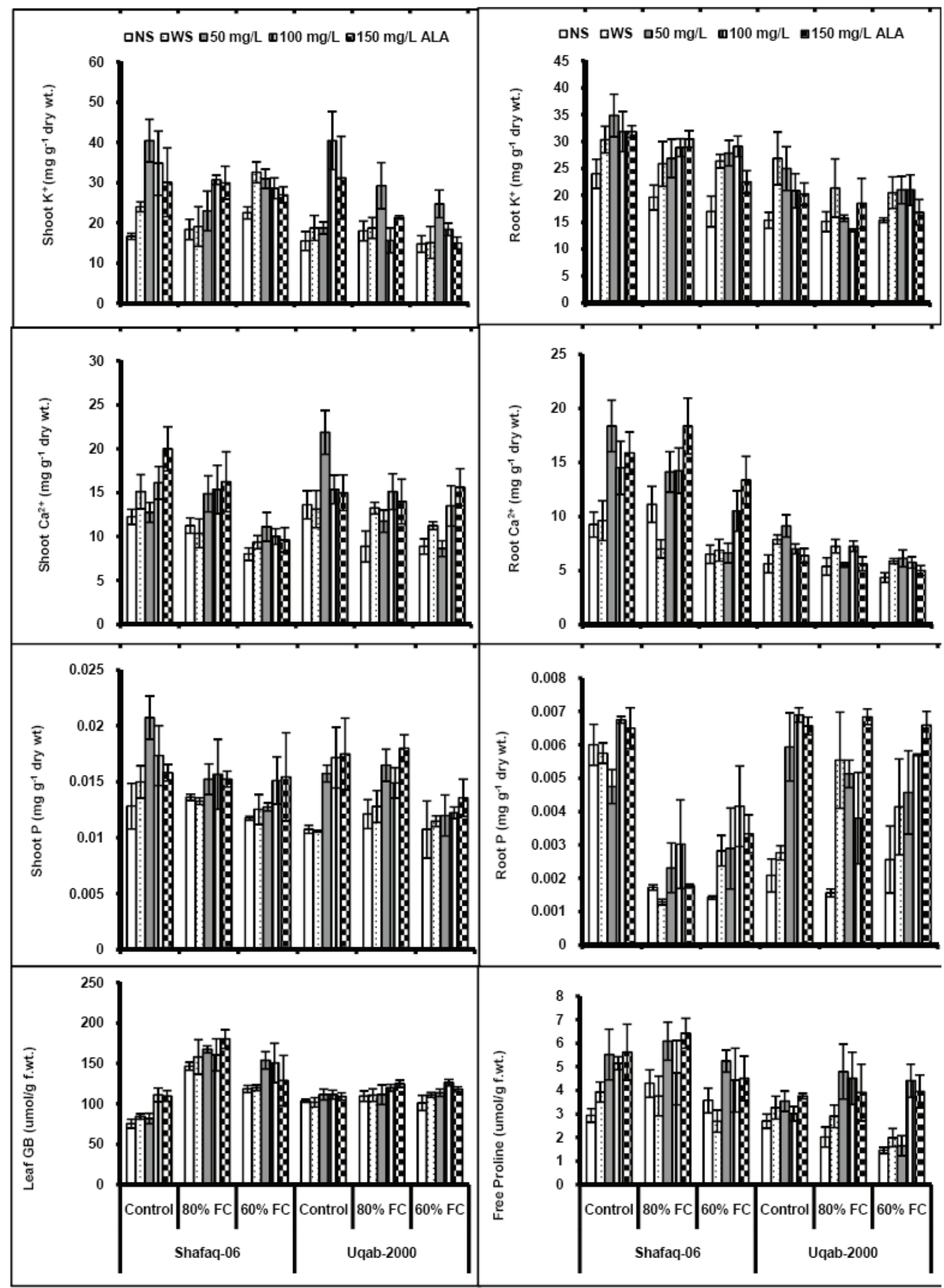

FIGURE 3. Leaf phenolics, malodialdehyde (MDA), hydrogen peroxide $\left(\mathrm{H}_{2} \mathrm{O}_{2}\right)$ contents and different yield [100-grain wt. (weight), number of grains per plant and yield per plant] attributes of wheat plants treated with aminolevulinic acid (ALA) foliarly at vegetative stage under control and drought stress $(60 \% \& 80 \%$ field capacity) conditions (Mean \pm S.E) 
high accumulation of proline in pepper plants under low temperature stress (Korkmaz et al. 2010), cucumber under heat stress (Zhang et al. 2012) and oilseed rape under $\mathrm{NaCl}$ stress (Naeem et al. 2011). Therefore, ALA-induced change in biosynthesis of osmoprotectants/osmolytes particularly under arid environment still needs to be explored.

No significant change in leaf total phenolic and MDA contents observed in both the wheat cultivars under drought stress conditions (Table 1). Overall, cultivar Uqab-2000 was significantly higher in MDA contents than cultivar Shafaq-06 under all the water regimes, and the response of both cultivars to water deficit conditions or ALA in terms of leaf total phenolics was almost same (Figure 3). Exogenously-applied ALA markedly increased both attributes in wheat plants subjected to water stress. These results are analogous to the observations of Liu et al. (2011) who found that exogenously-applied ALA (0.1$1.0 \mathrm{ppm}$ ) improved plant growth and chlorophyll, while inhibited MDA and ROS in Brasicca rapa under waterdeficit conditions. In addition, they also suggested that ALA could improve drought tolerance by maintaining growth due to improved antioxidants, while reduced ROS and MDA levels.

Yield in terms of yield per plant, grains per plant along with 100-grain weight decreased due to water stress markedly $(P \leq 0.001)$ in both wheat cultivars. However, ALA foliar spray significantly improved all yield related attributes under varying water stress conditions. Cultivar Uqab-2000 was considerably better in 100-grain weight and cultivar Shafaq-06 in number of grains and yield per plant under stress and/or non-stress conditions (Table 1; Figure 3). A considerable ALA-induced modulation in different physio-biochemical processes under stress conditions has been observed, but little information is available on the role of ALA in crop yield improvement under drought stress (Akram \& Ashraf 2013). In the present study, yield and yield related attributes of wheat plants decreased due to water stress in all the wheat plants, however foliar spray of ALA significantly improved all the yield related attributes of all the wheat plants under varying water regimes. ALA-induced improvement in grain yield has earlier been observed in wheat plants by Al-Thabet (2006). He ascribed this yield improvement to ALA-induced increase in water-use-efficiency and plant growth under drought stress. In another study, Al-Khateeb (2006) also observed improvement in drought-induced suppressed grain yield, spike length and number of grains which were positively correlated with ALA-induced improvement in rate of photosynthesis and stomatal conductance in barley plants. It is now widely known that ALA in low quantity augments chlorophyll synthesis resulting in enhanced photosynthesis, which in turn regulates growth and finally the yield of different crops (Akram \& Ashraf 2013).

\section{CONCLUSION}

Overall, ALA application considerably enhanced leaf chlorophyll pigments, $q N$, NPQ, $q P$, root and shoot $\mathrm{K}^{+}$,
$\mathrm{Ca}^{2+}$ and $\mathrm{P}$ accumulation, leaf proline, $\mathrm{GB}$, total phenolics, MDA contents and grain yield. Better growth and yield of cultivar Shafaq-06 than those of cultivar Uqab-2000 under water deficit regimes was found to be associated with ALA-induced improvement in leaf fluorescence $(q N$, $N P Q$ and $F_{v} / F_{m}$ ), shoot and root $\mathrm{K}^{+}$, root $\mathrm{Ca}^{2+}$, proline and GB accumulation.

\section{ACKNOWLEDGEMENTS}

The work presented in this manuscript is a part of research work conducted by M.Sc. scholars Miss Shamim Kausar and Naila Farid funded by the Higher Education Commission through project PM-IPFP/HRD/ HEC /2011/347.

\section{REFERENCES}

Akram, N.A. \& Ashraf, M. 2011a. Pattern of accumulation of inorganic elements in sunflower (Helianthus annuus L.) plants subjected to salt stress and exogenous application of 5-aminolevulinic acid. Pakistan Journal of Botany 43: 521-530.

Akram, N.A. \& Ashraf, M. 2011b. Improvement in growth, chlorophyll pigments and photosynthetic performance in salt-stressed plants of sunflower (Helianthus annuиs L.) by foliar application of 5-aminolevulinic acid. Agrochimica 55: 94-104.

Akram, N.A. \& Ashraf, M. 2013. Regulation in plant stress tolerance by a potential plant growth regulator, 5-aminolevulinic acid (ALA). Journal of Plant Growth Regulation 32: 663-679.

Akram, N.A., Shahbaz, M. \& Ashraf, M. 2007. Relationship of photosynthetic capacity and proline accumulation with the growth of differently adapted populations of two potential grasses (Cynodon dactylon (L.) Pers. and Cenchrus ciliaris L.) to drought stress. Pakistan Journal of Botany 39: 777-786.

Al-Khateeb, S.A. 2006. Promotive effect of 5-aminolevulinic acid on growth, yield and gas exchange capacity of barley (Hordeum vulgare L.) grown under different irrigation regimes. Journal of the Saudi Society of Agricultural Sciences 18: 103-111.

Al-Thabet, S.S. 2006. Promotive effect of 5-aminolevulinic acid on growth and yield of wheat grown under dry conditions. Journal of Agronomy 5: 45-49.

Arnon, D.T. 1949. Copper enzyme in isolated chloroplasts polyphenoloxidase in Beta vulgaris. Plant Physiology 24: $1-15$.

Ashraf, M. 2009. Biotechnological approach of improving plant salt tolerance using antioxidants as markers. Biotechnology Advances 27: 84-93.

Ashraf, M., Akram, N.A., Al-Qurainy, F. \& Foolad, M.R. 2011. Drought tolerance: Roles of organic osmolytes, growth regulators, and mineral nutrients. Advances in Agronomy 111: 249-296.

Ashraf, M. \& Khanum, A. 1997. Relationship between ion accumulation and growth in two spring wheat lines differing in salt tolerance at different growth stages. Journal of Agronomy and Crop Science 178: 39-51.

Bates, L.S., Waldren, R.P. \& Teare, I.D. 1973. Rapid determination of free proline for water stress studies. Plant Science 39: 205-207.

Carmak, I. \& Horst, J.H. 1991. Effects of aluminium on lipid peroxidation, superoxide dismutase, catalase and peroxidase 
activities in root tips of soybean (Glycine max). Physiologia Plantarum 83: 463-468.

Cha-um, S., Samphumphuang, T. \& Kirdmanee, C. 2013. Glycinebetaine alleviates water deficit stress in indica rice using proline accumulation, photosynthetic efficiencies, growth performances and yield attributes. Australian Journal of Crop Science 7: 213-218.

Dolatabadian, A., Sanavi, A.M. \& Sharifi, M. 2009. Alleviation of water deficit stress effects by foliar application of ascorbic acid on Zea mays L. Journal of Agronomy and Crop Science 195: 347-355.

Duke, S.O. \& Rebeiz, C.A. 1994. Porphyrin biosynthesis as a tool in pest management: An overview. In Porphyric Pesticides: Chemistry, Toxicology and Pharmaceutical Applications, edited by Duke, S.O. \& Rebeiz, C.A. Washington: American Chemical Society. pp. 1-17.

Grieve, C.M. \& Grattan, S.R. 1983. Rapid assay for determination of water soluble quaternary ammonium compounds. Plant and Soil 70: 303-307.

Iqbal, N., Ashraf, M.Y. \& Ashraf, M. 2005. Influence of water stress and exogenous glycinebetaine on sunflower achene weight and oil percentage. International Journal of Environmental Science and Technology 2: 155-160.

Jackson, M.L. 1962. Soil Chemical Analysis. London: Contable Co. Ltd.

Julkenen-Titto, R. 1985. Phenolic constituents in the leaves of northern willows: Methods for the analysis of certain phenolics. Journal of Agricultural and Food Chemistry 33: 213-217.

Korkmaz, A., Korkmaz, Y. \& Demirkiran, A.R. 2010. Enhancing chilling stress tolerance of pepper seedlings by exogenous application of 5-aminolevulinic acid. Environmental and Experimental Botany 67: 495-501.

Li, D., Zhang, J., Sun, W., Li, Q., Dai, A. \& Bai, J. 2011. 5-aminolevulinic acid pretreatment mitigates drought stress of cucumber leaves through altering antioxidant enzyme activity. Scientia Horticulturae 130: 820-828.

Liu, D., Wu, L., Naeem, M.S., Liu, H., Deng, X., Xu, L., Zhang, F. \& Zhou, W. 2013. 5-Aminolevulinic acid enhances photosynthetic gas exchange, chlorophyll fluorescence and antioxidant system in oilseed rape under drought stress. Acta Physiologiae Plantarum 9: 2747-2759.

Liu, D., Pei, Z.F., Naeem, M.S., Ming, D.F., Liu, H.B., Khan, F. \& Zhou, W.J. 2011. 5-Aminolevulinic acid activates antioxidative defense system and seedling growth in Brassica napus L. under water deficit stress. Journal of Agronomy and Crop Science 197: 284-295.

Liu, W.Q., Kang, L. \& Wang, L.J. 2006. Effect of 5-aminolevulinic acid (ALA) on photosynthesis and its relationship with antioxidant enzymes of strawberry leaves. Acta Botany Boreal-Occident Sinica 26: 57-62.

Maruyama-Nakashita, A., Hira, M.Y., Funada, S. \& Fuek, S. 2010. Exogenous application of 5-aminolevulinic acid increases the transcript levels of sulfur transport and assimilatory genes, sulfate uptake, and cysteine and glutathione contents in Arabidopsis thaliana. Soil Science and Plant Nutrition 56: 281-288.

Metwaly, M.M. 2012. Ecophysiological and anatomical responses of drought stressed wheat plants (Triticum aestivum L.) treating with some bacterial endophytes. Ph.D. Thesis, Faculty of Agriculture, Kafre El-Sheikh University, Kafre El-Sheikh, Egypt (Unpublished).

Mittler, R. 2002. Oxidative stress, antioxidants and stress tolerance. Trends in Plant Sciences 7: 405-410.
MSTAT Development Team. 1989. MSTAT User's Guide: A Microcomputer Program for the Design Management and Analysis of Agronomic Research Experiments. Michigan State University, East Lansing.

Naeem, M.S., Rasheed, M., Liu, D., Jin, Z.L., Ming, D.F., Yoneyama, K., Takeuchi, Y. \& Zhou, W.J. 2011 5-Aminolevulinic acid ameliorates salinity-induced metabolic, water-related and biochemical changes in Brassica napus L. Acta Physiologiae Plantarum 33: 517 528.

Naeem, M.S., Jin, Z.L., Wan, Z.L., Liu, D., Liu, H.B., Yoneyama, K. \& Zhou, W.J. 2010. 5-aminolevulinic acid improves photosynthetic gas exchange capacity and ion uptake under salinity stress in oilseed rape (Brassica napus L.). Plant and Soil 332: 405-415.

Navari-Izzo, F., Pinzino, C., Quartacci, M.F. \& Sgherri, C.L.M. 1994. Intracellular membranes: Kinetics of superoxide production and changes in thylakoids of resurrection plants upon dehydration and rehydration. Proceedings of the Royal Society of Edinburgh 102B: 187-191.

Nezhadahmadi, A., Prodhan, Z.H. \& Faruq, G. 2013. Drought tolerance in wheat. Scientific World Journal 2013: 610721.

Nishihara, E., Kondo, K., Parvez, M.M., Takahashi, K., Watanabe, K. \& Tanaka, K. 2003. Role of 5-aminolevulinic acid (ALA) on active oxygen-scavenging system in $\mathrm{NaCl}$-treated spinach (Spinacia oleracea). Journal of Plant Physiology 60: 1085-1091.

Pervez, M.A., Ayub, C.M., Khan, H.A., Shahid, M.A. \& Ashraf, I. 2009. Effect of drought stress on growth, yield and seed quality of tomato (Lycopersicon esculentum L.). Pakistan Journal of Agricultural Sciences 46: 174-178.

Sankar, B., Jaleel, C.A., Manivannan, P., Kishorekumar, A., Somasundaram, R. \& Panneerselvam, R. 2007. Droughtinduced biochemical modifications and proline metabolism in Abelmoschus esculentus (L.) Moench. Acta Botanica Croatica 66: 43-56.

Strasser, R.J., Srivastava, A. \& Govindgee. 1995. Polyphasic chlorophyll a flouresence transient in plants and cynobacteria. Photochemistry and Photobiology 61(1): 32-42.

Velikova, V., Yordanov, I. \& Edreva, A. 2000. Oxidative stress and some antioxidant systems in acid rain-treated bean plants. Protective role of exogenous polyamines. Plant Science 151: 59-66

Wang, L.J., Jiang, W.B., Liu, H., Liu, W.Q., Kang, L. \& Hou, X.L. 2005. Promotion by 5 -aminolevulinic acid of germination of pakchoi (Brassica campestris ssp. Chinensis var. communis Tsen et Lee) seeds under salt stress. Journal of Integrative Plant Biology 47: 1084-1091.

Wang, L.J., Shi, W., Liu, H., Liu, W.Q., Jiangm, W.B. \& Hou, X.L. 2004. Effects of exogenous 5-aminolevulinic acid treatment on leaf photosynthesis of pakchoi. Journal of Nanjing Agricultural University 47: 1084-1091.

Wang, L.J., Jiang, W.B., Zhang, Z., Yao, Q.H., Matsui, H. \& Ohara, H. 2003. Biosynthesis and physiological activities of 5-aminolevulinic acid (ALA) and its potential application in agriculture. Plant Physiology Communications 39: 185-192.

Watanabe, K., Tanaka, T., Hotta, Y., Kuramochi, H. \& Takeuchi, Y. 2000. Improving salt tolerance of cotton seedlings with 5-aminolevulinic acid. Plant Growth Regulation 32: 99-103.

Wolf, B. 1982. A comprehensive system of leaf analysis and its use for diagnosing crop nutrient status. Communications in Soil Science and Plant Analysis 13: 1035-1059. 
Youssef, T. \& Awad, M.A. 2008. Mechanisms of enhancing photosynthetic gas exchange in date palm seedlings (Phoenix dactylifera L.) under salinity stress by a 5 -aminolevulinic acid-based fertilizer. Journal of Plant Growth Regulation 27: $1-9$.

Zhang, J., Gao, Y., Yu, B., Xia, C.X. \& Bai, J.G. 2012. Pretreatment with 5-aminolevulinic acid mitigates heat stress of cucumber leaves. Biologia Plantarum 56: 780-784.

Nudrat Aisha Akram*, Shamim Kausar \& Naila Farid Department of Botany

Government College University Faisalabad

Pakistan
Muhammad Ashraf

Pakistan Science Foundation

Islamabad

Pakistan

Muhammad Ashraf \& Fahad Al-Qurainy Department of Botany and Microbiology King Saud University, Riyadh

Saudi Arabia

*Corresponding author; email: nudrataauaf@yahoo.com

Received: 23 May 2017

Accepted: 30 October 2017 